\title{
Treating nausea and vomiting in palliative care: a review
}

This article was published in the following Dove Press journal:

Clinical Interventions in Aging

9 September 201 I

Number of times this article has been viewed

\author{
Paul Glare \\ Jeanna Miller \\ Tanya Nikolova \\ Roma Tickoo \\ Pain and Palliative Care Service, \\ Department of Medicine, Memorial \\ Sloan-Kettering Cancer Center, \\ New York, NY, USA
}

Correspondence: Paul Glare Memorial Sloan-Kettering Cancer Center, I 275 York Avenue, New York, NY 10065, USA

Tel + I 6468883124

Fax + I 6464220937

Email glarep@mskcc.org
Abstract: Nausea and vomiting are portrayed in the specialist palliative care literature as common and distressing symptoms affecting the majority of patients with advanced cancer and other life-limiting illnesses. However, recent surveys indicate that these symptoms may be less common and bothersome than has previously been reported. The standard palliative care approach to the assessment and treatment of nausea and vomiting is based on determining the cause and then relating this back to the "emetic pathway" before prescribing drugs such as dopamine antagonists, antihistamines, and anticholinergic agents which block neurotransmitters at different sites along the pathway. However, the evidence base for the effectiveness of this approach is meager, and may be in part because relevance of the neuropharmacology of the emetic pathway to palliative care patients is limited. Many palliative care patients are over the age of 65 years, making these agents difficult to use. Greater awareness of drug interactions and QT ${ }_{c}$ prolongation are emerging concerns for all age groups. The selective serotonin receptor antagonists are the safest antiemetics, but are not used first-line in many countries because there is very little scientific rationale or clinical evidence to support their use outside the licensed indications. Cannabinoids may have an increasing role. Advances in interventional gastroenterology are increasing the options for nonpharmacological management. Despite these emerging issues, the approach to nausea and vomiting developed within palliative medicine over the past 40 years remains relevant. It advocates careful clinical evaluation of the symptom and the person suffering it, and an understanding of the clinical pharmacology of medicines that are available for palliating them.

Keywords: nausea, vomiting, palliative care

\section{Introduction}

In the specialist palliative care literature, nausea and vomiting have long been presented as common and distressing symptoms affecting the majority of patients. ${ }^{1}$ The cornerstone of the assessment and treatment of nausea and vomiting in palliative care has been based on the understanding of the "emetic pathway" and the main neurotransmitters involved in this process., ${ }^{2,3}$ This is because antiemetic drugs are predominately neurotransmitter-blocking agents at the different receptor sites involved in this process. The supposition has been that knowing where the various neurotransmitters occur in this pathway will lead to rational selection of antiemetic agents that will be effective in managing different causes of vomiting.

The value of this approach was emphasized in the case report "A woman with malignant bowel obstruction who did not want to die with tubes". ${ }^{4}$ An elderly patient with worsening nausea and vomiting due to a mechanical obstruction of the small 
bowel was well palliated with antiemetics (plus octreotide) until death occurred a short time later, averting the need for a laparotomy or placement of a drainage gastrostomy tube. Despite successful palliation outcomes obtained in such cases, the traditional approach to managing nausea and vomiting in palliative care has been challenged in recent years for a number of reasons:

- Surveys indicate these symptoms may be less common and bothersome than has previously been estimated.

- The emetic pathway was primarily determined to facilitate new drug development for chemotherapy-induced emesis and may not be particularly relevant to treating nausea and vomiting occurring in palliative care patients.

- When attempts are made to determine a cause in palliative care patients, either none can be found or else multiple causes are identifiable.

- Even if a single cause is identifiable, the neuropharmacology of the pathway is largely redundant, because many antiemetics have a broad spectrum of neurotransmitterblocking activity and work at multiple sites.

- The evidence base for this approach is modest, and the high response rates reported in case series and uncontrolled studies are often not borne out in the small number of well designed clinical trials that have been undertaken.

- Other pathways, such as the cytokine immunologic model of cancer symptoms, ${ }^{5}$ may also be relevant.

- Advances in interventional gastroenterology and radiology are increasing the options for nonpharmacological management.

Notwithstanding these challenges, the traditional approach still has merits even if its basic science is limited, because it provides a scholarly basis for approaching the pharmacological palliation of nausea and vomiting in patients with life-limiting illnesses. The traditional approach advocates careful clinical evaluation of the symptom and the person suffering it, and understanding the clinical pharmacology of the medicines that are available. The aim of this paper is to review the traditional approach to the assessment and treatment of chronic nausea and vomiting in patients with life-limiting illnesses in the light of the challenges listed above. Because many palliative care patients are over the age of 65 years, especially those with noncancer diagnoses, treatment of nausea and vomiting with antiemetic drugs can be more difficult in these geriatric patients than in younger ones. Physiologic changes such as diminished renal function, changes in body fat distribution, and alterations in hepatic metabolism, can lead to higher levels of medications and a greater susceptibility to adverse effects. ${ }^{6}$ Special reference will be made to pharmacological considerations that are necessary when prescribing antiemetics in older patients. Advances in health care and changing demographics worldwide have led to an aging population in whom care at the end of life has become increasingly complicated. ${ }^{7}$

While there is reasonably good evidence for the palliation of bowel obstruction, ${ }^{8}$ symptom management of the actively treated elderly cancer patient represents an undertreated and disproportionately understudied cohort in oncology. ${ }^{9}$ This is certainly the case for nausea and vomiting. A MEDLINE search retrieved no citations for "nausea and vomiting" or "palliative care", when limited to human subjects, English language, and age over 65 years. Entering the same terms in the clinical trials database maintained by the US National Library of Medicine (www.clinicaltrials.gov) identified 19 trials, but none evaluating pharmacological therapies in this population, and none being specifically for the elderly.

\section{Epidemiology of nausea and vomiting in palliative care}

Symptom research is complicated because many factors confound the patient's experience of symptoms. This is even more so in patients receiving palliative care because the observational studies needed are methodologically challenging for several reasons. ${ }^{10}$ Firstly, there is great heterogeneity in the clinical status of palliative care populations. They have many different primary diseases, at various stages. They often have symptomatic comorbidities. Secondly, differences in study setting, ie, hospital ward, outpatient clinic, inpatient unit, or home care, will impact on incidence and prevalence. Thirdly, nausea and vomiting tend to be treated as a single entity when they are not, eg, in one study, 62\% had both nausea and vomiting, 34\% had isolated nausea, and 4\% had isolated vomiting. ${ }^{11}$ Fourthly, the impact of treatment confounds the data-does one include a patient whose nausea and vomiting are currently completely relieved by antiemetic therapy, or not? Lastly, there is no standardized tool for measuring nausea and vomiting. ${ }^{12-14}$

Despite these methodological challenges, it now appears that nausea and vomiting may be less common and bothersome than has previously been estimated. A systematic review of the prevalence of common symptoms in patients with various life-limiting illnesses found that pain, breathlessness, and fatigue were all more common than nausea and vomiting. ${ }^{10}$ While the first three symptoms were each reported by more than $50 \%$ of patients with cancer, heart failure, renal failure, or the acquired immunodeficiency syndrome (AIDS), nausea and vomiting were only reported by $16 \%-68 \%$ of patients. Nausea and vomiting occurred most commonly in patients 
with AIDS, being reported by at least $43 \%$ of patients, followed by at least $30 \%$ of end-stage renal failure patients, at least $17 \%$ of heart failure patients, and at least $6 \%$ of cancer patients.

The findings of the above review have been confirmed in several recent studies of nausea and vomiting in palliative care populations. ${ }^{15-17}$ Nausea and vomiting do appear to become more common as death approaches, so it is not surprising that nausea has been found to be a predictor of a shortened survival in one study. ${ }^{18}$ In patients admitted to specialist palliative care programs, nausea has been reported by $36 \%$ patients at the first contact with the service, ${ }^{19-21} 62 \%$ at $1-2$ months before death, ${ }^{22,23}$ and $71 \%$ in the final week of life. ${ }^{24,25}$ However, in one study, the prevalence of nausea peaked in patients with a Karnofsky performance status score of 40, then decreased as performance status declined further, indicating it may often be aggravated by movement and alleviated by resting. ${ }^{26}$

While nausea is an unpleasant experience and nobody likes to vomit, these symptoms may be intermittent in palliative care patients, and are typically only mild to moderate in severity when present. Nausea was rated only 3-4 out of 10 in intensity in one study, ${ }^{17}$ and was moderate-to-severe (greater than 5 out of 10) in only a quarter of cases in another. ${ }^{27}$ In this sample, the impact of nausea and vomiting on general activity and emotional well being was rated as greater than 5 out of 10 by approximately $40 \%$ of patients. A recent, very large, population-based, prospective survey of 10 symptoms in ambulatory advanced cancer patients in Canada followed prospectively until death, found nausea was the least bothersome symptom, being moderate-severe in only $10 \%$ cases. ${ }^{16}$ Similar to pain, nausea and vomiting have been reported to be frequently undertreated, ${ }^{28}$ and perhaps surprisingly, it is the patients with more severe symptoms who often miss out on antiemetic therapy. ${ }^{29}$

In patients receiving palliative care, nausea and vomiting rarely occur in isolation. They tend to cluster with other symptoms like fatigue, drowsiness, decreased appetite, and dyspnea. ${ }^{30}$ Symptom clusters are important because they may independently predict changes in patient function, treatment failures, and post-therapeutic outcomes. Treatments directed at symptom clusters rather than individual symptoms may provide greater therapeutic benefit. In a review of symptom clustering in advanced cancer, many of the studies included found nausea and vomiting did cluster independently and not with other symptoms.

\section{Definitions of nausea and vomiting}

Clarification of the definitions of nausea, vomiting, and related phenomena is important for the correct assessment and treatment of these symptoms in patient receiving palliative care. This is because these terms are both poorly understood and incorrectly used. ${ }^{31}$ Nausea is an entirely subjective experience, defined as "the sensation (or sensations) that immediately precede vomiting". Patients state that they feel as if they are about to vomit, or describe the sensation as feeling "queasy" or "sick to the stomach". Vomiting, in contrast, is a highly specific physical event, defined as "the rapid, forceful evacuation of gastric contents in retrograde fashion from the stomach up to and out of the mouth". Vomiting is usually, but not always, proceeded by nausea. Retching is the repetitive, active contraction of the abdominal musculature, generating the pressure gradient which leads to evacuation of stomach contents. Retching may occur in isolation without discharge of gastric contents from the mouth, referred to as "dry heaves". Nausea and vomiting need to be distinguished from:

- Regurgitation - passive, retrograde flow of esophageal contents into the mouth. Regurgitation occurs with gastroesophageal reflux or esophageal obstruction.

- Rumination - an eating disorder which may be confused with vomiting. Rumination occurs repetitively after meals, is not preceded by nausea, and is not associated with the physical phenomena normally accompanying vomiting.

- Dyspepsia - chronic or recurrent pain or discomfort centered in the upper abdomen. Dyspepsia can be classified as structural (acid-related) or functional (dysmotility-related). ${ }^{32,33}$ Functional dyspepsia in cancer patients is called the cancer-associated dyspepsia syndrome,${ }^{34}$ characterized by nausea, early satiety, postprandial fullness, and pain.

\section{Causes of nausea and vomiting}

Nausea and vomiting is referred to as "chronic" if it is present for more than a few days, and the median duration in palliative care has been reported as seven days (range 1-468). ${ }^{17}$ Chronic nausea and vomiting present a greater diagnostic and therapeutic challenge than acute nausea and vomiting, and can usually be diagnosed readily on clinical grounds alone. There are many possible causes for nausea and vomiting in patients with advanced disease. ${ }^{35}$ The broad differential includes all the usual causes of nausea and vomiting shown in Table 3. In addition, etiologies specific to life-limiting illnesses need to be added to the list (see Table 1). It can be helpful to arrange the differential into the four categories which are used for classifying the etiology of cancer pain, ie, due to the primary disease, due to a side effect of therapy, secondary to 
Table I Categorization of nausea etiology in elderly palliative care patients with various life-threatening illnesses

\begin{tabular}{|c|c|c|c|c|c|}
\hline & Cancer & Cardiac failure & $\begin{array}{l}\text { Chronic obstructive } \\
\text { pulmonary disease }\end{array}$ & $\begin{array}{l}\text { End-stage } \\
\text { renal failure }\end{array}$ & Dementia \\
\hline Disease & $\begin{array}{l}\text { Liver metastases, } \\
\text { bowel obstruction }\end{array}$ & $\begin{array}{l}\text { Edema of } \\
\text { gastrointestinal tract }\end{array}$ & Post-tussive vomit & Uremia & - \\
\hline Treatment & $\begin{array}{l}\text { Chemotherapy, } \\
\text { opioids, NSAIDs }\end{array}$ & $\begin{array}{l}\text { Hyponatremia, } \\
\text { digoxin toxicity }\end{array}$ & $\begin{array}{l}\text { Antibiotics, } \\
\text { theophylline, }\end{array}$ & Dialysis, peritonitis & $\begin{array}{l}\text { Cholinesterase } \\
\text { inhibitors }\end{array}$ \\
\hline Debility & $\begin{array}{l}\text { Constipation, } \\
\text { esophageal candida, } \\
\text { anxiety, cachexia }\end{array}$ & $\begin{array}{l}\text { Constipation, } \\
\text { esophageal candida, } \\
\text { anxiety, cachexia }\end{array}$ & $\begin{array}{l}\text { Constipation, } \\
\text { esophageal candida, } \\
\text { anxiety, cachexia }\end{array}$ & $\begin{array}{l}\text { Constipation, } \\
\text { esophageal candida, } \\
\text { anxiety, cachexia }\end{array}$ & $\begin{array}{l}\text { Constipation, } \\
\text { esophageal candida, } \\
\text { tube feedings cachexia }\end{array}$ \\
\hline Unrelated & $\begin{array}{l}\text { Mesenteric ischemia, } \\
\text { subacute cholangitis, } \\
\text { Meniere's disease } \\
\text { gastroenteritis }\end{array}$ & $\begin{array}{l}\text { Mesenteric ischemia, } \\
\text { subacute cholangitis, } \\
\text { Meniere's disease } \\
\text { gastroenteritis }\end{array}$ & $\begin{array}{l}\text { Mesenteric ischemia, } \\
\text { subacute cholangitis, } \\
\text { Meniere's disease } \\
\text { gastroenteritis }\end{array}$ & $\begin{array}{l}\text { Mesenteric ischemia, } \\
\text { subacute cholangitis, } \\
\text { Meniere's disease } \\
\text { gastroenteritis }\end{array}$ & $\begin{array}{l}\text { Mesenteric ischemia, } \\
\text { subacute cholangitis, } \\
\text { Meniere's disease } \\
\text { gastroenteritis }\end{array}$ \\
\hline
\end{tabular}

Abbreviation: NSAIDs, nonsteroidal anti-inflammatory drugs.

debilitation, and caused by an unrelated comorbid condition. Because palliative care may be provided concurrent with disease-controlling treatment, entities such as chemotherapyinduced emesis and postoperative nausea and vomiting may also occur in this population. Discussion of these topics is beyond the scope of this review, but readers are referred to the various consensus guidelines for the management of these problems. ${ }^{36,37}$ In elderly palliative care patients, conditions such as mesenteric ischemia, subacute cholangitis, Meniere's disease, myocardial infarction, drug toxicity, constipation, and urinary tract infection need to be high on the differential diagnosis of nausea and vomiting. An etiology can be identified in approximately two thirds to three quarters of nauseated patients in palliative care. ${ }^{11,38,39}$ Multiple etiologies often coexist.

Certain demographic and clinical factors predict the development of nausea in palliative care patients. Nausea has been reported to be less common in patients over the age of 65 years. ${ }^{40}$ Other risk factors include female gender, ${ }^{40}$ specific tumor types (most notably gynecological, stomach, esophageal, and breast cancers) ${ }^{1,21}$ presence of metastases in the lung, pleura, or peritoneum ${ }^{41}$ gastrointestinal pathology or intestinal obstruction, ${ }^{42}$ and opioid medication. ${ }^{43}$

\section{Assessment of nausea}

There are four concurrent goals to be accomplished when evaluating the patient with advanced disease who reports nausea and vomiting:

- To clarify whether the patient is reporting nausea, dyspepsia, vomiting, retching, or regurgitation.

- To determine the etiology, in case it is easily reversed or treated.

- To document the intensity, frequency and associated distress. If possible, a patient-rated assessment of nausea should be obtained, preferably using a symptom assessment tool. ${ }^{12-14}$
The psychosocial and spiritual dimensions of suffering associated with the life-limiting illness should also be addressed, because these may contribute to the distress caused by the nausea and vomiting. ${ }^{44}$

- To commence appropriate antiemetic therapy. Unless the patient is actively dying, this should include identification and correction of any dehydration, electrolyte deficiencies, and acid-base disturbances caused by prolonged vomiting.

The history of the nausea and vomiting is the cornerstone to determining its etiology in palliative care. In addition to delineating the duration, frequency, and severity of the nausea and vomiting, the history should elicit a description of their characteristics and the nature of any associated symptoms. It is important to clarify if the nausea and vomiting are occurring together or in isolation. Associated problems such as reflux, gastric irritation, and constipation should be ruled out. There needs to be a review of the home medication list. The history should include sentinel questions which aid determination of the chronic nausea syndrome. Six have been described: ${ }^{11,39}$

- Intermittent nausea associated with early satiety and postprandial fullness or bloating. The nausea is relieved by vomiting that is usually small volume, occasionally forceful, and may contain food. This clinical picture suggests impaired gastric emptying. This is the cause in $35 \%-45 \%$ cases of nausea and vomiting.

- Persistent nausea, aggravated by the sight and smell of food, unrelieved by vomiting. This suggests chemical causes, activating the chemoreceptor trigger zone. It is found in $30 \%-40 \%$ cases.

- Intermittent nausea associated with abdominal cramps and altered bowel habit. The nausea is relieved by vomiting that may become large in volume and bilious or 
feculent. This suggests a bowel obstruction and is the cause in $10 \%-30 \%$ cases.

- Early morning nausea and vomiting associated with headache. This suggests raised intracranial pressure.

- Nausea aggravated by movement, including motion sickness or even just turning the head. This indicates a vestibular component.

- Nausea and vomiting associated with anxiety, suggesting a cortical component.

The last three clinical pictures occur in $<15 \%$ cases. The putative etiology derived from the history is then confirmed by the physical examination (eg, fever, uremic appearance, abdominal tenderness, hepatomegaly, diminished bowel sounds, pulmonary edema) and on review of any relevant blood tests and radiology. Ordering an abdominal x-ray is worth considering, except in the most terminally ill patient, to help rule out constipation, bowel obstruction, or perforation. Unless the history and examination specifically suggests upper gastrointestinal mucosal disease or an abnormality of motor function, tests such as esophagogastroduodenoscopy, small bowel series, gastric emptying studies, electrogastrography, or antroduodenal manometry would not normally be ordered in palliative care patients (see Table 2).

Regular reassessment should occur daily to ensure that the symptoms remain controlled. This includes reassessment of the severity of nausea and vomiting, and the effectiveness

Table 2 Assessment of the elderly palliative care patient with nausea and vomiting

\begin{tabular}{l} 
History \\
Quality: nausea, vomiting, retching, regurgitation \\
Duration \\
Persistent or intermittent \\
Intensity \\
Associated vomiting, nature of vomitus, relief from vomiting \\
Associated pain, altered bowel habit \\
Aggravating factors: sight/smell of food, worse after eating, movement \\
Temporal factors: worse in morning \\
Relieving factors eg, vomiting \\
Drug history: opioids, nonsteroidal anti-inflammatory drugs, antibiotics \\
Anticancer treatment \\
Physical examination \\
Abdomen: organomegaly, other masses, bowel sounds \\
(ileus or mechanical obstruction), rectal examination \\
Other: signs of sepsis, metabolic abnormalities (liver failure, renal failure, \\
hypercalcemia), neurological signs \\
Investigations \\
Radiology: abdominal x-ray, computed tomography scan, magnetic \\
resonance imaging \\
Laboratory tests: rule out sepsis, renal failure, hypercalcemia \\
\hline
\end{tabular}

Table 3 Chronic nausea and vomiting syndromes in palliative care patients with advanced cancer

\begin{tabular}{|c|c|}
\hline Syndrome & Examples \\
\hline \multirow[t]{10}{*}{ Gastric stasis } & Cancer-related \\
\hline & - Carcinoma of stomach \\
\hline & - Hepatomegaly or ascites ("squashed stomach") \\
\hline & - Paraneoplastic neuropathy \\
\hline & Treatment-related: \\
\hline & - Drug-induced, eg, opioids \\
\hline & Comorbidities: \\
\hline & • Dyspepsia \\
\hline & - Gastritis (including drug-related, eg, NSAIDS) \\
\hline & - Diabetic gastroparesis \\
\hline \multirow[t]{12}{*}{ Biochemical } & Cancer-related \\
\hline & - Hypercalcemia \\
\hline & - Liver metastases \\
\hline & - Obstructive uropathy \\
\hline & - Bowel obstruction \\
\hline & • “Toxins” (anorexia-cachexia syndrome) \\
\hline & Treatment-related \\
\hline & - Drugs: opioids, chemotherapy \\
\hline & Comorbidities \\
\hline & - Organ failures \\
\hline & - Infections \\
\hline & - Drugs: antibiotics, SSRI antidepressants \\
\hline Raised intracranial & Cancer-related \\
\hline \multirow[t]{3}{*}{ pressure } & - Brain tumors \\
\hline & - Cerebral secondaries \\
\hline & - Meningeal disease \\
\hline \multirow[t]{6}{*}{ Vestibular } & Cancer-related \\
\hline & - Cerebral secondaries \\
\hline & Treatment related \\
\hline & - Drugs, eg, opioids \\
\hline & Comorbidities \\
\hline & - Motion sickness, vestibular problems \\
\hline \multirow{9}{*}{$\begin{array}{l}\text { Bowel obstruction/ } \\
\text { dysmotility }\end{array}$} & Cancer-related \\
\hline & - Bowel primary \\
\hline & -Intra-abdominal secondaries \\
\hline & (eg, peritoneal disease) \\
\hline & - Ascites \\
\hline & Treatment-related \\
\hline & - Adhesions \\
\hline & Debility \\
\hline & - Constipation \\
\hline Other & - Anxiety \\
\hline
\end{tabular}

Abbreviations: NSAIDs, nonsteroidal anti-inflammatory drugs; SSRIs, selective serotonin reuptake inhibitors.

of the antiemetic regimen, and other treatment strategies. A recurrence or exacerbation of previously controlled nausea and vomiting requires a full re-evaluation.

\section{Approaches to pharmacological treatment of nausea}

Pharmacological agents are the principal method for palliating nausea and vomiting in patients with life-limiting diseases. There are two different approaches to drug selection, 
which may be referred to as empirical and mechanistic. The empirical approach leaves antiemetic drug selection to physician preference. In contrast, the mechanistic approach applies our current understanding of the neuropharmacology of the "emetic pathway" to the selection of the antiemetic agents (see Figure 1). ${ }^{45}$ These sites contain receptors for one or more neurotransmitter, including dopamine type $2\left(\mathrm{D}_{2}\right)$, serotonin types $2-4\left(5 \mathrm{HT}_{2-4}\right)$, histamine type $1\left(\mathrm{H}_{1}\right)$, and acetylcholine (muscarinic receptors type 1 to $5, \mathrm{M}_{1-5}$ ). Other receptors such as substance $\mathrm{P}$, cannabinoid type $1\left(\mathrm{CB}_{1}\right)$ and the endogenous opioids may also be implicated, although their precise sites are uncertain. Antiemetic selection is based on knowing which drugs block the receptors found in the structure where the cause of the nausea and vomiting is acting on, inferred from the clinical assessment discussed earlier. The neurotransmitter receptors at which the various antiemetic drugs are known to work are shown in Table 4. The selected agent should be titrated to effect. If the patient does not respond to one agent, a second agent should be added, combining agents from different classes.

While the mechanistic approach is based on clinical science, it has limitations in that the etiology of chronic nausea in advanced disease is often unidentifiable or multifactorial, many of the drugs act on multiple receptors, and other pathways may also be operating. ${ }^{5}$ Therefore, a more empiric approach is justifiable. Because most cases are due to gastroparesis or mediated via the chemoreceptor trigger zone, treatment should be initiated with a dopamine antagonist. In patients who do not respond to a dopamine antagonist, agents from different classes are combined. In patients with refractory nausea and vomiting, a broad spectrum agent which blocks multiple neurotransmitters should be added, such as olanzapine or methotrimeprazine.

Data on the effectiveness of the palliative care approach to choosing which antiemetic to prescribe is limited. Effectiveness of the individual antiemetic agents is discussed in the next section. Using the mechanistic approach, controlled studies of antiemetics in specific syndromes, such as cancer-associated dyspepsia syndrome and opioid-induced nausea have produced mixed results. Case series involving some 200 heterogeneous episodes found symptoms were controlled in 60\%-90\% cases, and residual symptoms were generally mild. ${ }^{11,39,46}$ On the other hand, three randomized trials and one observational study have evaluated the empirical approach..$^{34,47-49}$ These studies are hard to synthesize and none was placebo-controlled. Nevertheless, low-dose metoclopramide (10 $\mathrm{mg}$ three times a day) was effective in $30 \%-40 \%$ of cases. Other agents, including a dopamine antagonist (in one of two studies) and a serotonin antagonist (one study) were superior to the other therapies. There have been no head-to-head comparisons of the mechanistic and empiric approaches. Cochrane reviews and other systematic

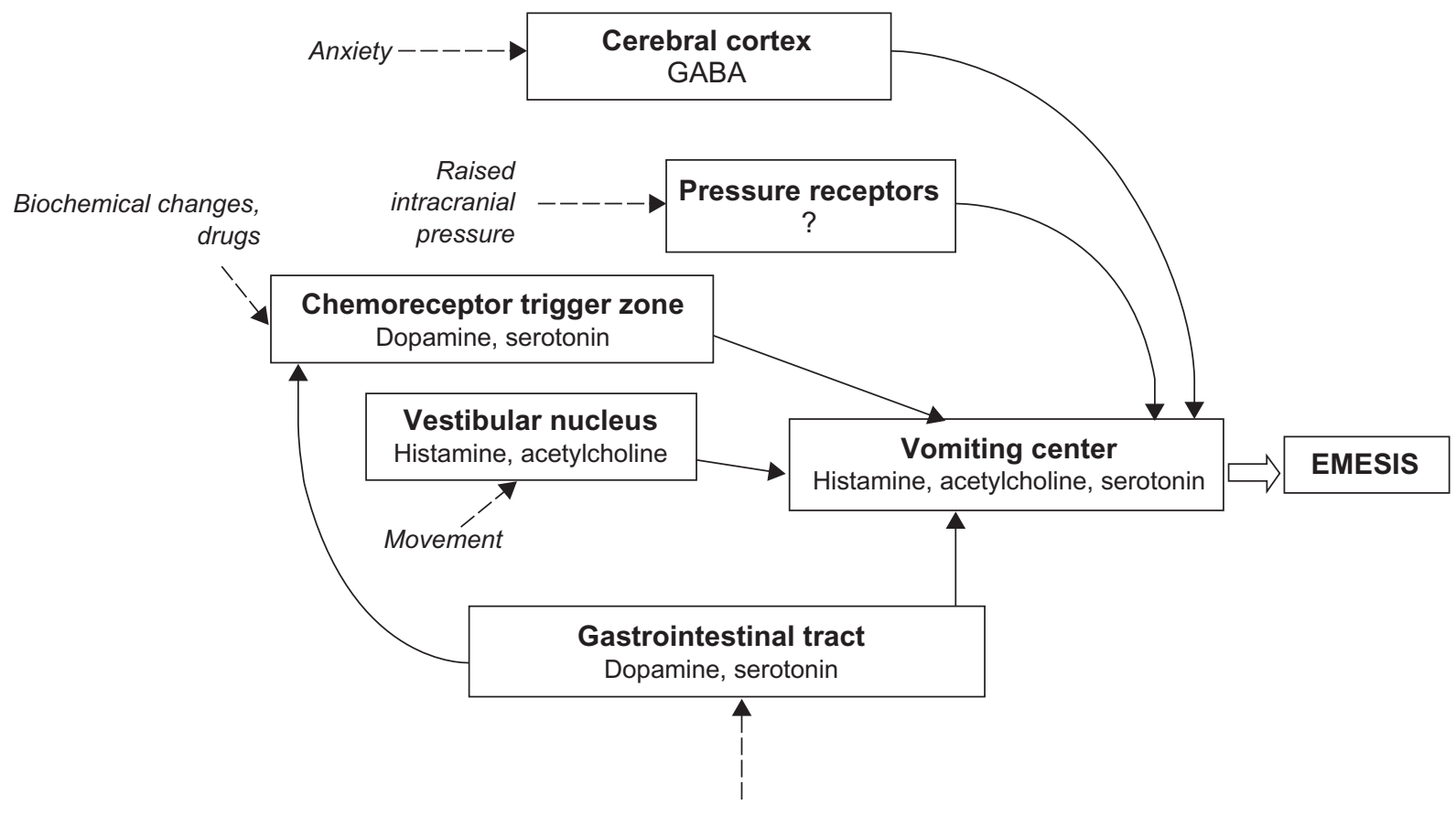

Gastric stasis, constipation, bowel obstruction

Figure I The emetic pathway. 
Table 4 Receptor site affinities of commonly used antiemetics ${ }^{2,54,142}$

\begin{tabular}{|c|c|c|c|c|c|c|}
\hline Drug & $\begin{array}{l}\text { Dopamine } \\
\text { antagonist }\end{array}$ & $\begin{array}{l}\text { Histamine } \\
\text { antagonist }\end{array}$ & $\begin{array}{l}\text { Acetylcholine } \\
\text { (muscarinic) } \\
\text { antagonist }\end{array}$ & $\begin{array}{l}\text { Serotonin } \\
\text { type } 2 \text { antagonist }\end{array}$ & $\begin{array}{l}\text { Serotonin } \\
\text { type } 3 \text { antagonist }\end{array}$ & $\begin{array}{l}\text { Serotonin } \\
\text { type } 4 \text { agonist }\end{array}$ \\
\hline \multicolumn{7}{|l|}{ Chlorpromazine } \\
\hline \multicolumn{7}{|l|}{ Cisapride } \\
\hline \multicolumn{7}{|l|}{ Cyclizine } \\
\hline \multicolumn{7}{|l|}{ Domperidone } \\
\hline \multicolumn{7}{|l|}{ Haloperidol } \\
\hline \multicolumn{7}{|l|}{ Hyoscine } \\
\hline \multicolumn{7}{|l|}{ Levomepromazine } \\
\hline \multicolumn{7}{|l|}{ Metoclopramide } \\
\hline \multicolumn{7}{|l|}{ Ondansetron } \\
\hline \multicolumn{7}{|l|}{ Prochlorperazine } \\
\hline Promethazine & & & & & & \\
\hline
\end{tabular}

Notes: Black, high affinity for receptor; dark gray, moderate affinity; light gray, low affinity; white, no known affinity.

reviews of treatment of nausea and vomiting in palliative care have been attempted, but the evidence that has been identified is sparse. ${ }^{50-52}$ Consequently, there is a dearth of specific recommendations or guidelines regarding drug selection, dosing, and side effects which account for changes in aging physiology, pharmacokinetics, and idiosyncratic reactions other than what is provided in pharmacology texts.

\section{Drugs for treating nausea and vomiting \\ Prokinetic agents}

Prokinetic agents stimulate the motility of the upper gastrointestinal tract by four potential mechanisms: activation of $5 \mathrm{HT}_{4}$ receptors, releasing acetylcholine from enteric neurons to stimulate the cholinergic system in the gut wall; blockade of $5 \mathrm{HT}_{3}$ receptors, ${ }^{33,54}$ activation of motilin receptors; ${ }^{55}$ or releasing the dopaminergic "brake" on gastric emptying. ${ }^{56}$ Prokinetic agents should not be used when stimulation of muscular contractions might adversely affect the gut, for example, in complete bowel obstruction, gastrointestinal hemorrhage, perforation, or immediately following surgery. These prokinetic effects are blocked by antimuscarinic agents, including antihistamine antiemetics. Therefore, it makes no sense to prescribe a prokinetic and an antimuscarinic agent together.

Metoclopramide is the only prokinetic agent that is currently widely available. It works on the stomach and proximal small bowel, but has little effect on colonic motility. In addition to its prokinetic effects, metoclopramide also antagonizes $\mathrm{D}_{2+}$ receptors in the chemoreceptor trigger zone. The pharmacokinetics of metoclopramide are summarized in Table 5, along with most other antiemetics discussed in this section.
The prokinetic dose of metoclopramide is $10 \mathrm{mg}$ three or four times a day, administered half an hour before meals and at bedtime. The central $\mathrm{D}_{2}$ antagonist effect of metoclopramide in the chemoreceptor trigger zone is only achieved with high doses (10 mg every 4-6 hours, orally or parenterally, maximum daily dose $100 \mathrm{mg}$ ). Dose reductions are recommended in moderate to severe renal impairment, with a $50 \%$ decrease recommended if the creatinine clearance is $10-40 \mathrm{~mL} / \mathrm{min}$, and a $75 \%$ reduction if the creatinine clearance is $<10 \mathrm{~mL} / \mathrm{min}^{57,58}$ In elderly patients, the initial dose should be at the lower end of the recommended adult range.

The most common side effects of metoclopramide are restlessness, drowsiness, and fatigue. Assessments for involuntary movements are recommended for elderly patients using metoclopramide at high doses and for long-term therapy. To highlight the risk of tardive dyskinesia from metoclopramide, the US Food and Drug Administration has added a "black box warning" to the information leaflet for prescribers; administration beyond 12 weeks is not recommended. Pretreatment with diphenhydramine will prevent the acute extrapyramidal symptoms with high-dose metoclopramide, ${ }^{59}$ but may block the peripheral prokinetic effects. Other precautions relevant to the elderly when prescribing metoclopramide include Parkinson's disease, high blood pressure, kidney problems, liver problems, heart failure, and diabetes. Clinically important drug interactions are uncommon with metoclopramide because it is a minor substrate of the cytochrome P450 (CYP) 1A2 and 2D6 isoenzymes and a weak inhibitor of CYP 2D6.

Three small placebo-controlled trials have evaluated the effectiveness of metoclopramide, ${ }^{34,60,61}$ but the results are conflicting. Metoclopramide was superior to placebo in cancer-associated dyspepsia syndrome, ${ }^{34}$ but not in 
Table 5 Pharmacokinetics of selected antiemetic drugs

\begin{tabular}{|c|c|c|c|c|c|}
\hline Drug & BA (\%) & Onset (h) & $\mathbf{T}_{\max }(\mathbf{h})$ & $t_{1 / 2}(h)$ & Duration (h) \\
\hline Chlorpromazine ${ }^{143}$ & $10-69$ & - & PO: $2-4$ IM: $0.5-I$ & $8-35$ & $>24$ \\
\hline Cisapride $^{71}$ & $40-50$ & $0.5-1$ & $\mathrm{I}-2$ & $7-10$ & $12-16$ \\
\hline Cyclizine $^{144}$ & & $<2$ & 2. & 7,24 & $4-6$ \\
\hline Dexamethasone ${ }^{100}$ & $6 I-86$ & $8-24$ & $\mathrm{I}-2$ & 4 & $36-54$ \\
\hline Domperidone $e^{56,65,145,146}$ & $13-17$ & 0.5 & 0.5 & $7.5-16$ & $8-16$ \\
\hline Haloperidol ${ }^{73}$ & $60-65$ & PO: > I SC: $0.15-0.25$ & PO: I.7-6 IM: 0.3-0.5 & $14-36$ & - \\
\hline Hyoscine butylbromide & $8-10$ & PO: I-2 SC: $0.25-0.5$ & - & $5-6$ & - \\
\hline Hyoscine hydrobromide ${ }^{147}$ & Not applicable & SL: $0.15-0.25$ & $0.15-0.5$ & $5-6$ & $0.25-10$ \\
\hline Levomepromazine $e^{76}$ & 50 & 0.5 & PO: I-3 IM 0.5-I.5 & $15-30$ & $12-24$ \\
\hline Metoclopramide ${ }^{148}$ & $32-100$ & $\begin{array}{l}\text { IV: } 0.0 \mathrm{I}-0.05 \text { IM: } 0.15-0.25 \\
\text { PO: } 0.5-\mathrm{I}\end{array}$ & $<1$ & $4-6$ & $\mathrm{I}-2$ \\
\hline Octreotide ${ }^{149,150}$ & Not applicable & - & $<0.5$ & 1.5 & $8-12$ \\
\hline Olanzapine $^{|5|}$ & $60-80$ & - & PO: 5-8 IM: 0.25-0.75 & $21-54$ & \\
\hline Prochlorperazine $e^{152,153}$ & 12.5 & & $1.5-5$ & $6.8-9$ & \\
\hline Promethazine $^{154,155}$ & 25 & & PO: 2-3 & $10-14$ & $4-12$ \\
\hline \multicolumn{6}{|l|}{ Serotonin antagonists } \\
\hline Dolasetron ${ }^{156,157}$ & 76 & - & IV: 0.6 PO: I.4 & $6.6-8.8$ & \\
\hline Granisetron ${ }^{158}$ & 60 & - & PO: 2 & $10-12$ & \\
\hline Ondansetron ${ }^{159-161}$ & $60-70$ & - & IV: 0.1 PO: $0.5-2$ & $2.5-5.4$ & \\
\hline Palonosetron ${ }^{162,163}$ & N/A & - & & 40 & \\
\hline Tropisetron ${ }^{164,165}$ & $60-100$ & PO: $1-1.3$ & & $8-40$ & \\
\hline
\end{tabular}

Abbreviations: BA, bioavailability; $\mathrm{T}_{\max }$, time to reach maximum blood concentration (in hours); $\mathrm{t}_{1 / 2}$, elimination half-life; IM intramuscular; IV, intravenous; PO, oral; SC, subcutaneous; SL, sublingual; N/A, not available.

opioid-induced nausea ${ }^{60}$ In a Spanish study, levosulpiride was superior to metoclopramide, effective in approximately $85 \%$ versus $40 \%$ of cases. ${ }^{61}$

Other agents with prokinetic activity include mirtazapine $^{62}$ and erythromycin. Erythromycin acts by stimulating motilin receptors in the upper gastrointestinal tract. ${ }^{55} 5 \mathrm{HT} 3$ receptors may also be involved in this process. ${ }^{63}$ There are no data for its use in palliative care, but it has been shown to be effective in diabetic gastroparesis. ${ }^{64}$ The prokinetic dose is $250 \mathrm{mg}$ three times a day by mouth or $250-500 \mathrm{mg}$ per day intravenously. Side effects include impaired hepatic function and prolongation of the $\mathrm{QT}_{\mathrm{c}}$ interval on the electrocardiogram. Domperidone and cisapride are effective prokinetic drugs that were formerly available, ${ }^{54,65}$ but have either been removed or are restricted because of their potential for cardiac toxicity associated with QT prolongation. $^{66-68}$ Domperidone does not cross the blood-brain barrier, so only acts at peripheral dopamine receptors, releasing the "dopaminergic brake". As a result, extrapyramidal symptoms are much less likely with it. Cisapride is a pure $5 \mathrm{HT}_{4}$ receptor agonist that is devoid of any $\mathrm{D}_{2}$ antagonist activity, and is able to increase the motility of the entire length of the gastrointestinal tract. ${ }^{69-71}$ It is prone to many drug interactions via CYP 3A4 which increases its blood levels and aggravates its arrhythmogenic effect.

\section{Dopamine receptor antagonists}

Phenothiazines and other antipsychotic agents, such as haloperidol and olanzapine, block $\mathrm{D}_{2}$ receptors found in the chemoreceptor trigger zone. ${ }^{3}$ All but haloperidol has a broad spectrum of activity, also blocking histaminic, muscarinic, serotonergic, and/or alpha-adrenergic receptors. They may also produce vagal blockade in the gastrointestinal tract, giving them some prokinetic activity. They are also used in malignant bowel obstruction. Because of their broad activity, these agents cause many side effects, most notably sedation, hypotension, and anticholinergic side effects, dystonias, and extrapyramidal symptoms. They may prolong the QT interval, lower the white blood cell count, and lower seizure thresholds. Due to their side effect profile, they are not ideal agents to use in the elderly. These agents carry a "black box warning" about precipitation of psychosis in demented elderly patients. There is an increased risk of death compared with placebo, although most deaths are either cardiovascular or infectious in nature and not specifically related to the drug.

Prochlorperazine and chlorpromazine are two phenothiazines which are commonly used as antiemetics. The antiemetic dose of prochlorperazine is 5-10 $\mathrm{mg}$ three times a day or four times a day orally, $25 \mathrm{mg}$ twice a day or three times a day rectally, or 5-10 mg every 3-4 hours (to a maximum of $40 \mathrm{mg}$ daily) intramuscularly. The initial geriatric dose is $2.5-5 \mathrm{mg}$ once or twice daily, increased once or twice 
a week by $2.5-5 \mathrm{mg} /$ day, and the maximum daily dose should not exceed $75 \mathrm{mg}$. The antiemetic dose of chlorpromazine is $10-25 \mathrm{mg}$ every $4-6$ hours or $25-50 \mathrm{mg}$ every $3-4$ hours, orally. ${ }^{2}$ Dose reduction should be considered in the elderly and in patients with liver dysfunction. Chlorpromazine is more sedating than prochlorperazine, ${ }^{72}$ and this can be doselimiting, although it may be useful in a distressed dying patient. Prochlorperazine should also be avoided in patients with an absolute neutrophil count of $<1000$ cells/ $\mu \mathrm{L}$ because of the risk of neutropenia. Other side effects are common, including confusion, respiratory depression, extrapyramidal symptoms, and anticholinergic effects. Gradual titration may prevent some side effects or decrease their severity. General precautions in the elderly include glaucoma and prostate hypertrophy.

Haloperidol, a butyrophenone, is a more potent and pure $\mathrm{D}_{2}$ receptor blocker than the other agents. ${ }^{2}$ Antiemetic doses of haloperidol are $1.5-5 \mathrm{mg}$ twice a day or three times a day by mouth, or $0.5-2 \mathrm{mg}$ intravenously every 8 hours, and are lower than usual antipsychotic doses. The side effects of haloperidol are similar to those of the phenothiazines, except that haloperidol causes less sedation and hypotension. It causes more extrapyramidal symptoms, and patients with Parkinson's disease may be more sensitive to its adverse effects, so it should be avoided in them. Haloperidol may also have enough anticholinergic activity to exacerbate narrow-angle glaucoma. Caution and dose reduction is recommended in patients with severe hepatic impairment. Haloperidol is a substrate of CYP $3 \mathrm{~A} 4$, so coadministration with carbamazepine, phenytoin, phenobarbital, rifampicin, or quinidine may alter the clinical pharmacokinetics of haloperidol. It is a moderate inhibitor of CYP 2D6, but this has been reported to be of questionable clinical significance. ${ }^{73}$

Levomepromazine is utilized as second-line or third-line therapy for refractory nausea and vomiting in palliative care. ${ }^{74}$ It also has analgesic properties. ${ }^{75}$ The dose is $6.25-25 \mathrm{mg}$ twice a day, or $25-50 \mathrm{mg} /$ day via continuous subcutaneous infusion. It presents the same potential problems in the elderly as the other dopamine antagonists, with anticholinergic effects, confusion, hallucinations, and dystonic reactions all possible. Compared with chlorpromazine, it is more sedative and more likely to cause postural hypotension. ${ }^{74}$ It should be administered cautiously in renal or hepatic impairment. ${ }^{76}$ It may prolong the QT interval.

Olanzapine is an atypical antipsychotic with high affinity for multiple dopamine $\left(\mathrm{D}_{1}, \mathrm{D}_{2}, \mathrm{D}_{4}\right)$, serotonin $\left(5 \mathrm{HT}_{2 \mathrm{~A}}, 5 \mathrm{HT}_{2 \mathrm{C}}\right.$, $\left.5 \mathrm{HT}_{3}\right), \alpha_{1}$-adrenergic, $\mathrm{H}_{1}$, and cholinergic $\left(\mathrm{M}_{1-5}\right)$ receptors. ${ }^{77,78}$ It has been used as an antiemetic in palliative care. ${ }^{79}$ The usual antiemetic dose is $5-10 \mathrm{mg} /$ day by mouth. ${ }^{59} \mathrm{~A}$ lower starting dose $(2.5-5 \mathrm{mg} /$ day $)$ is recommended for elderly or debilitated patients, which may be increased as tolerated with close monitoring of orthostatic blood pressure. Olanzapine causes fewer extrapyramidal symptoms than other antipsychotics, ${ }^{80,81}$ and it does not usually cause $\mathrm{QT}_{\mathrm{c}}$ prolongation at conventional doses. Its main side effects are somnolence and weight gain. Dry mouth, constipation, increased appetite, agitation, hyperglycemia, and edema have also been reported. ${ }^{81}$ Olanzapine is only a weak inhibitor of the CYP isoenzymes, so drug interactions are not usually an issue. Precautions to consider in the elderly palliative care patient when prescribing olanzapine include severe cardiac disease, hemodynamic instability, prior myocardial infarction, ischemic heart disease, or hypercholesterolemia, Parkinson's disease, and renal or hepatic impairment.

Although haloperidol and the other dopamine antagonists are frequently used for nausea or vomiting in palliative care, the evidence supporting their use is scant:

- Prochlorperazine - there are no data for this agent as an antiemetic in advanced cancer. It is significantly less effective than high-dose metoclopramide for chemotherapy-induced emesis. ${ }^{82}$

- Chlorpromazine - in large randomized controlled trials of empiric prescribing of antiemetics, ${ }^{49}$ chlorpromazinecontaining combinations were effective only $20 \%-30 \%$ of the time.

- Haloperidol - there have not been any randomized controlled trials of haloperidol for the other chronic nausea syndromes in palliative care other than malignant bowel obstruction. ${ }^{50,83,84}$ There have been randomized controlled trials of haloperidol in postoperative nausea and vomiting, gastrointestinal disorders, and prophylaxis against chemotherapy-induced emesis. The number-needed-to-treat for haloperidol $2 \mathrm{mg}$ to prevent postoperative nausea and vomiting was four. ${ }^{85}$

- Olanzapine - there are no randomized controlled trials of olanzapine for chronic nausea in palliative care. Two small case series with subjective outcome assessment indicated that olanzapine appears to be effective in cases that were refractory to other agents. ${ }^{86}$

- Levomepromazine - there have not been any randomized controlled trials of levomepromazine in palliative care. In one case series, levomepromazine was used effectively as the first-line agent in $12 \%$ of patients; two other patients were switched to it when not responding to other agents. ${ }^{39}$ In other case series, it was effective in $60 \%-80 \%$ cases. $^{37,87}$ 


\section{Antihistaminic agents}

The first generation of piperazine class $\mathrm{H}_{1}$ receptor antagonists block $\mathrm{H}_{1}$ receptors in the vomiting center of the medulla, ${ }^{88}$ the vestibular nucleus, and the chemoreceptor trigger zone..$^{89,90}$ The antimuscarinic activity does reduce mucosal secretory activity, which is helpful in bowel obstruction. There are many drugs in this class, including promethazine, cyclizine, meclizine, hydroxyzine, and diphenhydramine, all of which have potential as antiemetics.

Promethazine is widely prescribed for motion sickness and vestibular disorders, but may also help in emesis related to raised intracranial pressure. It has little anticholinergic activity. The antiemetic dose is $25 \mathrm{mg}$ orally or intravenously every 4-6 hours (maximum $100 \mathrm{mg} /$ day). ${ }^{91}$ The lowest doses should be used, and in divided doses to avoid side effects . The main side effect is sedation, although tolerance usually develops quickly. Promethazine theoclate may cause less drowsiness than promethazine maleate. As with phenothiazines, the piperazine $\mathrm{H}_{1}$ receptor antagonists may cause dizziness, extrapyramidal symptoms, headache, constipation, urinary retention, and lowering of the seizure threshold. It is recommended to limit the use of promethazine in the elderly, and discontinue it when not effective, due to its anticholinergic side effects. They may cause confusion or aggravate symptoms of confusion in those with dementia. $\mathrm{H}_{1}$ blockers should be used with caution in patients with narrow-angle glaucoma, prostatic hyperplasia, cardiovascular disease, severe hypertension, respiratory compromise, impaired hepatic function, and epilepsy.

Other $\mathrm{H}_{1}$ antagonists, such as diphenhydramine, dimenhydrinate, hydroxyzine, meclizine, and cyclizine, are mentioned as antiemetics in palliative care texts. They vary in their muscarinic activity, and those with more antimuscarinic activity, such as cyclizine, may be useful for bowel obstruction. ${ }^{92}$ All are problematic in geriatric populations, but diphenhydramine and hydroxyzine have a high risk for a severe adverse outcome on the Beers criteria, which rate a drug's tendency to cause side effects in the elderly due to the physiologic changes of aging. ${ }^{93}$ Therefore, they are the least desirable in this population. Being a moderate CYP 2D6 inhibitor, diphenhydramine may diminish the metabolic activation and therapeutic effects of codeine, tramadol, and tamoxifen, which are potentially relevant in a palliative care population. Although prochlorperazine is mainly a dopamine antagonist, it also has some antihistamine activity and may be effective for mild cases of nausea due to a vestibular mechanism.

There are few published data for using $\mathrm{H}_{1}$ blockers as antiemetics in palliative care. There have been no randomized controlled trials, ${ }^{94}$ but in one uncontrolled trial of the mechanistic approach to treating nausea, $5 \%-10 \%$ cases were initially treated with cyclizine, apparently successfully. ${ }^{39}$

\section{Selective $5 \mathrm{HT}_{3}$ receptor antagonists}

The selective $5 \mathrm{HT}_{3}$ receptor antagonists exert their antiemetic effect via blockade of peripheral and central $5-\mathrm{HT}_{3}$ receptors. These receptors are found on the vagus nerve, which feeds into the emetic center, the enterochromaffin cells of the peripheral enteric nervous system, and in the nucleus tractus solitarius and chemoreceptor trigger zone. ${ }^{95}$ The $5 \mathrm{HT}_{3}$ receptor antagonists block the amplifying effect of serotonin on the vagus nerve. They are primarily used for chemotherapyinduced emesis and have a limited role in palliative care where they are generally reserved as third-line agents for refractory cases. They have also been shown to be effective in bowel obstruction and renal failure, both of which are also associated with excess serotonin release.

Ondansetron is the oldest selective $5 \mathrm{HT}_{3}$ receptor antagonist. Newer ones include granisetron, tropisetron, dolasetron, and palonosetron. The recommended dose of ondansetron for chronic nausea is 4-8 $\mathrm{mg}$ given once or twice a day. Appropriate doses of the other agents are $1 \mathrm{mg}$ twice a day for granisetron, $200 \mathrm{mg}$ once a day for dolasetron, and $0.25 \mathrm{mg}$ intravenously once a day for palonosetron. Side effects of these agents are usually mild and transient. Constipation, which may occur in $5 \%-10 \%$ of patients, is the biggest potential problem for palliative care patients. All selective $5 \mathrm{HT}_{3}$ receptor antagonists are metabolized by CYP isoenzymes, although the extent of metabolism and the specific isoenzymes involved differs for each drug. This has potentially significant clinical implications for patients receiving multiple medications. The selective $5 \mathrm{HT}_{3}$ receptor antagonists may decrease the efficacy of tramadol. They should be used cautiously with drugs that prolong the $\mathrm{QT}_{\mathrm{c}}$ interval. In severe hepatic impairment, the maximum dose is $8 \mathrm{mg}$ /day. ${ }^{96}$

The selective $5 \mathrm{HT}_{3}$ receptor antagonists have been associated with a number of dose-dependent increases in electrocardiographic intervals including QT/QT . Reduction in heart rate may also occur with these agents but they are considered to be reasonably safe in the elderly. Even though the elderly have a slightly decreased hepatic clearance rate of ondansetron, this does not require dose adjustment.

It is noteworthy that several other antiemetic agents have nonselective activity at serotonin receptors. Metoclopramide is a weak $5 \mathrm{HT}_{3}$ receptor antagonist as well as a $5 \mathrm{HT}_{4}$ agonist (contributing to its prokinetic effect). Cisapride is a more 
potent $5 \mathrm{HT}_{4}$ agonist than metoclopramide, without $5 \mathrm{HT}_{3}$ antagonist activity. Olanzapine has activity at $5 \mathrm{HT} 2{ }_{\mathrm{A}} 5 \mathrm{HT} 2$, and $5 \mathrm{HT}_{3}$. The antidepressant mirtazapine also has some activity as a $5 \mathrm{HT}_{3}$ receptor antagonist. ${ }^{62}$ Levomepromazine is a potent $5 \mathrm{HT}_{2}$ antagonist but has no activity at the $5 \mathrm{HT}_{3}$ or $5 \mathrm{HT}_{4}$ receptor; this $5 \mathrm{HT}_{2}$ antagonism may be important for controlling nausea.

Although there is high-level evidence for $5 \mathrm{HT}_{3}$ receptor antagonist agents in chemotherapy-induced emesis, ${ }^{97}$ the evidence of benefit for refractory nausea in palliative and supportive care is less strong. ${ }^{49,60,98}$ There have been two randomized controlled trials of $5 \mathrm{HT}_{3}$ receptor antagonists in advanced cancer. ${ }^{49,60}$ In one study, tropisetron was much more effective than conventional antiemetics (metoclopramide and chlorpromazine) for any cause of nausea in cancer patients. ${ }^{49}$ In the other study, there were no significant differences between ondansetron, metoclopramide, and placebo for opioid-induced nausea in patients with advanced cancer. ${ }^{60}$ Control of emesis and partial control of nausea was achieved in approximately $50 \%$ of patients on the active agents, compared with $33 \%$ receiving placebo, but the difference was not significant. An uncontrolled case series of ondansetron, with rigorous outcome assessment, showed that it is effective as a second-line agent in $80 \%$ of patients.

\section{Other agents}

\section{Corticosteroids}

Corticosteroids have mainly been studied as antiemetics in chemotherapy-induced emesis, in the management of malignant bowel obstruction, ${ }^{97,99}$ and raised intracranial pressure. They are also used as second-line therapy in chronic nausea of advanced cancer. ${ }^{48}$ Steroids are said to act "centrally", but the precise antiemetic mechanism of action of steroids is unknown. Possible mechanisms include depletion of gamma aminobutyric acid stores in the medulla, reduction of bloodbrain barrier permeability to emetic toxins, and inhibition of enkephalin release in the brainstem. ${ }^{88}$ The usual antiemetic dose of dexamethasone is 4-8 $\mathrm{mg}$ /day for chronic nausea and up to $16 \mathrm{mg}$ /day for malignant bowel obstruction or raised intracranial pressure. ${ }^{8}$ The lowest possible dose should be used for the briefest period, with withdrawal or reduction considered when maximal effect has been obtained, an adequate trial (approximately 7-10 days) has failed to achieve the desired effect, or if side effects occur. If dexamethasone is to be continued long term, prophylactic cotrimoxazole for prevention of Pneumocystis pneumonia is recommended. Because of its many side effects and toxicities, ${ }^{100}$ dexamethasone needs to be used with caution in diabetics, patients with a psychiatric history, and perioperatively. It may be contraindicated in patients on palliative chemotherapy because of the risk of sepsis or masking a fever. There is limited and conflicting data on the benefit of steroids in chronic nausea due to nonspecific causes in terminal cancer. ${ }^{88}$ Reported efficacy rates vary from less than $20 \%$ to greater than $75 \% .{ }^{48,49}$ Randomized controlled trials are lacking, but an uncontrolled trial of metoclopramide found $75 \%$ cases were controlled when steroids were added as second-line agents.

\section{Benzodiazepines}

Short-acting benzodiazepines such as lorazepam are frequently administered to nauseated patients, ${ }^{72}$ but they are only minimally effective as antiemetics. Rather, their sedative, anxiolytic, and amnesic properties may enhance the effectiveness of other antiemetic regimens and they may prevent the development of anticipatory emesis. They are most useful when nausea and vomiting is associated with anxiety. Benzodiazepines are generally to be avoided in elderly patients because of their high severity rating on the Beers criteria. If a benzodiazepine must be used, lorazepam is preferred because it is relatively short-acting and has inactive metabolites.

\section{Hyoscine}

Pure anticholinergic agents such as hyoscine (also known as scopolamine) are used as antiemetics. Because they relax smooth muscle and reduce gastrointestinal secretions via blockade of muscarinic receptors, they are also useful in the medical management of terminal bowel obstruction. Formulations (with antiemetic dose ranges) include hyoscine butylbromide (80-120 mg daily, via continuous subcutaneous infusion) and hyoscine hydrobromide (given orally, $0.1-0.4 \mu \mathrm{g}$ every four hours, subcutaneously or intravenously, $0.6-2.4 \mathrm{mg}$ daily via continuous infusion, or 1-3 mg transdermally, changed every third day). The anticholinergic effects of hyoscine are a potential problem in the elderly.

\section{Octreotide}

This somatostatin analog is used for the palliation of malignant bowel obstruction, especially when there is high output vomiting not responding to other measures (steroids, haloperidol, hyoscine, and a proton pump inhibitor). In this situation, octreotide reduces secretion of fluids by the intestine and pancreas, ${ }^{101}$ reduces gastrointestinal motility, and causes vasoconstriction. It has also been shown to produce analgesic effects, most probably acting as a partial agonist at the $\mu$-opioid receptor. ${ }^{102}$ The dose used for bowel obstruction is 
$100 \mu \mathrm{g}$ subcutaneously three times daily or $100-600 \mu \mathrm{g}$ per day via intravenous or continuous subcutaneous infusion. The most common (in more than $10 \%$ of patients) side effects of octreotide are local skin reactions, including pain, stinging, burning, and gastrointestinal effects, including cramps, nausea/vomiting, diarrhea or constipation, and gallstones. Headache, hypothyroidism, and cardiac toxicity, including bradycardia and $\mathrm{QT}_{\mathrm{c}}$ prolongation, may be common. Because of its effects on insulin and other hormones, it should be used with caution in patients with diabetes mellitus and other endocrinopathies, renal failure, and hepatic impairment.

\section{Cannabinoids}

Many jurisdictions are currently considering the legalization of "medical marijuana", and there are data for the efficacy of cannabinoids in chemotherapy-induced emesis and the anorexia-cachexia syndrome. ${ }^{103,104}$ There is little clinical evidence for the efficacy of cannabinoids in nausea and vomiting in palliative care, other than a few case reports. The antiemetic effect is thought to be subtended via $\mathrm{CB}_{1}$ receptors which are ubiquitous in brain tissue, ${ }^{103,105}$ but whether they are found within specific structures of the emetic pathway is unclear. Short duration of action and side effects are a major problem of current commercial formulations, such as dronabinol, especially in the elderly, who may be more sensitive to the central nervous system effects and postural hypotensive effects. ${ }^{106}$ The dose should be titrated slowly, with close monitoring for adverse effects. Drug interactions are uncommon, but the central nervous system depressant effects may be potentiated when used with other psychoactive drugs, sedatives, and/or ethanol.

\section{Other modes of nausea control}

Nondrug measures are also important in the management of nausea and vomiting in palliative care. Avoidance of environmental stimuli, such as sights, sounds, or smells that may initiate nausea are recommended. ${ }^{107}$ Fatty, spicy, and highly salted food should be avoided. Fish oil supplements failed to improve nausea, appetite, or tiredness in patients with advanced cancer. ${ }^{108}$

Behavioral approaches, such as relaxation and distraction, may decrease psychological arousal and distress by refocusing the patient's attention on something else, and increase the patient's feelings of control over the symptoms. ${ }^{109}$ There have been few studies of these therapies in the chronic nausea of advanced cancer unrelated to anticancer treatment. Relaxation training which utilizes progressive muscle relaxation and guided imagery has been successful in reducing chemotherapy-induced emesis in some studies ${ }^{110,111}$ but not others. ${ }^{112}$ Massage has been reported to be effective for nausea and pain in bone marrow transplant patients. ${ }^{113}$ Foot massage was shown to reduce nausea significantly in hospitalized cancer patients. ${ }^{114}$

A systematic review of complementary and alternative medicine for symptom management at the end of life was unable to identify any large-scale trials in terminally ill patients for nausea and vomiting. Only studies for chemotherapy-induced emesis could be found. ${ }^{115}$ Acupuncture and ginger have been shown to be effective for chemotherapyinduced emesis and anticipatory nausea, ${ }^{51,116}$ but have not been evaluated in the nausea of far advanced disease.

\section{Nonsurgical procedures in palliation of cancer-related nausea and vomiting}

While some patients prefer to die without tubes, as presented in the case history in the Introduction, ${ }^{4}$ palliation of nausea and vomiting may be achieved more quickly and effectively in patients with advanced disease who are not amenable to surgery when draining percutaneous gastrostomy tubes, gastrointestinal stents, and other endoscopic techniques are utilized. Progress in interventional gastroenterology makes these approaches less risky and burdensome than they used to be.

Three percent of all advanced cancers lead to malignant bowel obstruction, particularly bowel cancer and ovarian cancer. ${ }^{1,117}$ In fact, some $25 \%-50 \%$ patients with ovarian cancer experience at least one episode of malignant bowel obstruction. Surgery may not be an option when there is diffuse intraperitoneal metastasis with multiple areas of obstruction or advanced stage of disease with very short life expectancy. In this situation, other modalities such as percutaneous endoscopic gastrostomy (PEG) placement can be considered. ${ }^{118}$ Nasogastric tubes are less invasive than a PEG tube but should not be used over an extended period of time. Nasogastric tubes risk frequent displacement, poor tolerance, and restrictions in ambulation and daily routine activities. Complications of nasogastric tubes include aspiration, hemorrhage, gastric erosion, alar necrosis, and sinusitis or otitis.

The most common approach for placement of gastrostomy tubes is endoscopic. The success rate of PEG placement is very high, in the range of $89 \%-100 \%,{ }^{119-122}$ and symptomatic improvement can usually be expected. Once a PEG tube is placed, most patients are able to go home or into an inpatient hospice facility to die. Most can take sips, liquids, or a soft diet, with or without the tube being clamped. 
PEG tube maintenance is relatively simple but does require education of the patient and their informal caregivers. The complication rate of PEG tubes has been summarized in a review of seven studies involving almost 300 patients. In the largest series, major and minor complications of PEG placement affected $18 \%$ of the patients, with half of them (9\%) complaining of ascites and leakage. ${ }^{119}$ Other reported complications in this series included peristomal infection, tube obstruction, tube migration, and wound bleeding. In a small study utilizing the Symptom Distress Scale, $64 \%$ of patients reported improvement in nausea, vomiting, intestinal motility, insomnia, weakness, mood, and concentration 7 days after PEG placement. ${ }^{123}$

Partial or complete obstruction by tumors of the esophagus, stomach, duodenum, or colon are frequently complicated by nausea and vomiting. Blockage of the lumen by tumor may occur directly or by extrinsic compression. In locally advanced esophageal cancer, palliative management of an obstructing lesion includes alcohol injection, ${ }^{124,125}$ laser therapy, ${ }^{126,127}$ argon plasma coagulation, ${ }^{128}$ photodynamic therapy, and esophageal stent placement, which can be plastic, ${ }^{129-131}$ or metallic. ${ }^{132-136}$ Stent migration rates are reported to range from $6 \%$ to $25 \%$. Gastric outlet obstruction is associated with vomiting undigested food hours after eating. The most common nonsurgical treatment is enteral stent placement. ${ }^{137}$ Because gastric outlet obstruction is frequently associated with biliary tract obstruction, simultaneous placement of a biliary stent and an enteral stent is recommended.

In malignant large bowel obstruction, colonic decompression tubes, laser therapy, argon plasma coagulation, and selfexpanding metal stents have all been employed. Colonic decompression tube placement is often used to provide air (and not necessarily stool) passage in patients who need clinical stabilization before surgery. ${ }^{138}$ The stents used for large bowel obstruction are self-expanding metallic stents. Studies that compared self-expanding metallic stents with surgery have shown the benefits of self-expanding metallic stent placement, including a decreased length of hospitalization and cost. ${ }^{139-141}$

\section{Conclusion}

Recent large surveys and reviews indicate that nausea and vomiting are less frequent and distressing in patients at the end of life than other symptoms, such as pain, fatigue, or breathlessness. Data for the efficacy of antiemetic agents in advanced cancer are limited, and where they exist they are often conflicting. Novel agents are also needed, but the known neuropharmacology of the antiemetic pathway may not be the most appropriate paradigm for chronic nausea from other causes. Novel agents, such as cannabinoids and anticytokine antibodies, may prove useful. In the meantime, more studies are needed of both the existing drugs and the different approaches to selecting them (empirical versus mechanistic). To achieve valid and reliable results, these studies will need to overcome many methodological challenges that are encountered when studying symptoms in patients with advanced diseases.

\section{Disclosure}

None of the authors has any proprietary or financial interests in any of the drugs mentioned in this study. None has a financial arrangement with the companies that make any of these products.

\section{References}

1. Baines MJ. ABC of palliative care. Nausea, vomiting, and intestinal obstruction. BMJ. 1997;315(7116):1148-1150.

2. Peroutka SJ, Snyder SH. Antiemetics: neurotransmitter receptor binding predicts therapeutic actions. Lancet. 1982;1(8273):658-659.

3. Grunberg SM, Hesketh PJ. Control of chemotherapy-induced emesis. N Engl J Med. 1993;329(24):1790-1796.

4. Steadman K, Franks A. A woman with malignant bowel obstruction who did not want to die with tubes. Lancet. 1996;347(9006):944.

5. Cleeland CS, Bennett GJ, Dantzer R, et al. Are the symptoms of cancer and cancer treatment due to a shared biologic mechanism? A cytokineimmunologic model of cancer symptoms. Cancer. 2003;97(11): 2919-2925.

6. Bishop TF, Morrison RS. Geriatric palliative care - Part I: pain and symptom management. Clin Geriatr. 2007;15(1):25-32.

7. Sutton LM, Demark-Wahnefried W, Clipp EC. Management of terminal cancer in elderly patients. Lancet Oncol. 2003;4(3):149-157.

8. Feuer DJ, Broadley KE. Corticosteroids for the resolution of malignant bowel obstruction in advanced gynaecological and gastrointestinal cancer. Cochrane Database Syst Rev. 2000;3:CD001219.

9. Barford KL, D’Olimpio JT. Symptom management in geriatric oncology: practical treatment considerations and current challenges. Curr Treat Options Oncol. 2008;9(2-3):204-214.

10. Solano JP, Gomes B, Higginson IJ. A comparison of symptom prevalence in far advanced cancer, AIDS, heart disease, chronic obstructive pulmonary disease and renal disease. J Pain Symptom Manage. 2006;31(1):58-69.

11. Stephenson J, Davies A. An assessment of aetiology-based guidelines for the management of nausea and vomiting in patients with advanced cancer. Support Care Cancer. 2006;14(4):348-353.

12. Bruera E, Kuehn N, Miller MJ, Selmser P, Macmillan K. The Edmonton Symptom Assessment System (ESAS): a simple method for the assessment of palliative care patients. J Palliat Care. 1991;7(2):6-9.

13. Portenoy RK, Thaler HT, Kornblith AB, et al. The memorial symptom assessment scale: an instrument for the evaluation of symptom prevalence, characteristics and distress. Eur J Cancer. 1994;30A(9): 1326-1336.

14. Melzack R, Rosberger Z, Hollingsworth ML, Thirlwell M. New approaches to measuring nausea. CMAJ. 1985;133(8):755-758.

15. Sigurdardottir KR, Haugen DF. Prevalence of distressing symptoms in hospitalised patients on medical wards: a cross-sectional study. $B M C$ Palliat Care. 2008; 7:16.

16. Seow H, Barbera L, Sutradhar R, et al. Trajectory of performance status and symptom scores for patients with cancer during the last six months of life. J Clin Oncol. 2011;29(9):1151-1158. 
17. Yates P. Clinical and patient perspectives on factors contributing to nausea in advanced cancer. Oncol Nurs Forum. 2006;33(2):468-469.

18. Chang VT, Hwang SS, Kasimis B, Thaler HT. Shorter symptom assessment instruments: the Condensed Memorial Symptom Assessment Scale (CMSAS). Cancer Invest. 2004;22(4):526-536.

19. Ventafridda V, De Conno F, Ripamonti C, Gamba A, Tamburini M. Quality-of-life assessment during a palliative care programme. Ann Oncol. 1990;1(6):415-420.

20. Donnelly S, Walsh D, Rybicki L. The symptoms of advanced cancer: identification of clinical and research priorities by assessment of prevalence and severity. J Palliat Care. 1995;11(1):27-32.

21. Vainio A, Auvinen A. Prevalence of symptoms among patients with advanced cancer: an international collaborative study. Symptom Prevalence Group. J Pain Symptom Manage. 1996;12(1):3-10.

22. Reuben DB, Mor V. Nausea and vomiting in terminal cancer patients. Arch Intern Med. 1986;146(10):2021-2023.

23. Coyle N, Adelhardt J, Foley KM, Portenoy RK. Character of terminal illness in the advanced cancer patient: pain and other symptoms during the last four weeks of life. J Pain Symptom Manage. 1990;5(2):83-93.

24. Fainsinger R, Miller MJ, Bruera E, Hanson J, Maceachern T. Symptom control during the last week of life on a palliative care unit. $J$ Palliat Care. 1991;7(1):5-11.

25. Conill C, Verger E, Henriquez I, et al. Symptom prevalence in the last week of life. J Pain Symptom Manage. 1997;14(6):328-331.

26. Mercadante S, Casuccio A, Fulfaro F. The course of symptom frequency and intensity in advanced cancer patients followed at home. J Pain Symptom Manage. 2000;20(2):104-112.

27. Bruera E, Neumann C, Brenneis C, Quan H. Frequency of symptom distress and poor prognostic indicators in palliative cancer patients admitted to a tertiary palliative care unit, hospices, and acute care hospitals. J Palliat Care. 2000;16(3):16-21.

28. Reuben D. Nausea and vomiting in terminal cancer patients. Arch Intern Med. 1986;146(10):2021-2023.

29. Greaves J, Glare P, Kristjanson LJ, Stockler M, Tattersall MH. Undertreatment of nausea and other symptoms in hospitalized cancer patients. Support Care Cancer. 2009;17(4):461-464.

30. Cheung WY, Le LW, Zimmermann C. Symptom clusters in patients with advanced cancers. Support Care Cancer. 2009;17(9):1223-1230.

31. Quigley EM, Hasler WL, Parkman HP. AGA technical review on nausea and vomiting. Gastroenterology. 2001;120(1):263-286.

32. Meineche-Schmidt V, Christensen E. Classification of dyspepsia. Identification of independent symptom components in 7270 consecutive, unselected dyspepsia patients from general practice. Scand J Gastroenterol. 1998;33(12):1262-1272.

33. Talley NJ, Phillips SF. Non-ulcer dyspepsia: potential causes and pathophysiology. Ann Intern Med. 1988;108(6):865-879.

34. Bruera E, Belzile M, Neumann C, Harsanyi Z, Babul N, Darke A. A double-blind, crossover study of controlled-release metoclopramide and placebo for the chronic nausea and dyspepsia of advanced cancer. J Pain Symptom Manage. 2000;19(6):427-435.

35. American Gastroenterological Association. Medical position statement: nausea and vomiting. Gastroenterology. 2001;120(1):261-263.

36. Gan TJ, Meyer T, Apfel CC, et al. Consensus guidelines for managing postoperative nausea and vomiting. Anesth Analg. 2003;97(1):62-71.

37. Jordan K, Sippel C, Schmoll HJ. Guidelines for antiemetic treatment of chemotherapy-induced nausea and vomiting: past, present, and future recommendations. Oncologist. 2007;12(9):1143-1150.

38. Lichter I. Nausea and vomiting in patients with cancer. Hematol Oncol Clin North Am. 1996;10(1):207-220.

39. Bentley A, Boyd K. Use of clinical pictures in the management of nausea and vomiting: a prospective audit. Palliat Med. 2001;15(3):247-253.

40. Walsh D, Donnelly S, Rybicki L. The symptoms of advanced cancer: relationship to age, gender, and performance status in 1,000 patients. Support Care Cancer. 2000;8(3):175-179.

41. Morita T, Tsunoda J, Inoue S, Chihara S. Contributing factors to physical symptoms in terminally-ill cancer patients. J Pain Symptom Manage. 1999;18(5):338-346.
42. Mercadante S, Fulfaro F, Casuccio A. The impact of home palliative care on symptoms in advanced cancer patients. Support Care Cancer. 2000;8(4):307-310.

43. Meuser T, Pietruck C, Radbruch L, Stute P, Lehmann KA, Grond S. Symptoms during cancer pain treatment following WHO guidelines: a longitudinal follow-up study of symptom prevalence, severity and etiology. Pain. 2001;93(3):247-257.

44. Turner J, Zapart S, Pedersen K, Rankin N, Luxford K, Fletcher J. Clinical practice guidelines for the psychosocial care of adults with cancer. Psychooncology. 2005;14(3):159-173.

45. Hesketh PJ. Chemotherapy-induced nausea and vomiting. N Engl J Med. 2008;358(23):2482-2494.

46. Lichter I. Results of antiemetic management in terminal illness. J Palliat Care. 1993;9(2):19-21.

47. Bruera ED, MacEachern TJ, Spachynski KA, et al. Comparison of the efficacy, safety, and pharmacokinetics of controlled release and immediate release metoclopramide for the management of chronic nausea in patients with advanced cancer. Cancer. 1994;74(12):3204-3211.

48. Bruera E, Seifert L, Watanabe S, et al. Chronic nausea in advanced cancer patients: a retrospective assessment of a metoclopramide-based antiemetic regimen. J Pain Symptom Manage. 1996;11(3):147-153.

49. Mystakidou K, Befon S, Liossi C, Vlachos L. Comparison of the efficacy and safety of tropisetron, metoclopramide, and chlorpromazine in the treatment of emesis associated with far advanced cancer. Cancer. 1998;83(6):1214-1223.

50. Perkins P, Dorman S. Haloperidol for the treatment of nausea and vomiting in palliative care patients. Cochrane Database Syst Rev. 2009;2:CD006271

51. Ezzo JM, Richardson MA, Vickers A, et al. Acupuncture-point stimulation for chemotherapy-induced nausea or vomiting. Cochrane Database Syst Rev. 2006;2:CD002285.

52. Clark K, Agar MR, Currow D. Metoclopramide for chronic nausea in adult palliative care patients with advanced cancer (Protocol). Cochrane Database Syst Rev. 2010(2).

53. Walkembach J, Bruss M, Urban BW, Barann M. Interactions of metoclopramide and ergotamine with human 5-HT(3 A) receptors and human 5-HT reuptake carriers. Br J Pharmacol. 2005;146(4):543-552.

54. De Maeyer JH, Lefebvre RA, Schuurkes JA. 5-HT4 receptor agonists: similar but not the same. Neurogastroenterol Motil. 2008;20(2): 99-112.

55. Cuomo R, Vandaele P, Coulie B, et al. Influence of motilin on gastric fundus tone and on meal-induced satiety in man: role of cholinergic pathways. Am J Gastroenterol. 2006;101(4):804-811.

56. Schuurkes JAJ, Helsen LFM, Ghoos ECR, Eelen JGMG, van Nueten JM. Stimulation of gastroduodenal motor activity: dopaminergic and cholinergic modulation. Drug Dev Res. 1986;8(1-4):233-241.

57. Magueur E, Hagege H, Attali P, Singlas E, Etienne JP, Taburet AM. Pharmacokinetics of metoclopramide in patients with liver cirrhosis. Br J Clin Pharmacol. 1991;31(2):185-187.

58. Bateman DN, Gokal R, Dodd TR, Blain PG. The pharmacokinetics of single doses of metoclopramide in renal failure. Eur J Clin Pharmacol. 1981;19(6):437-441.

59. Santucci G, Mack JW. Common gastrointestinal symptoms in pediatric palliative care: nausea, vomiting, constipation, anorexia, cachexia. Pediatr Clin North Am. 2007;54(5):673-689.

60. Hardy J, Daly S, McQuade B, et al. A double-blind, randomised, parallel group, multinational, multicentre study comparing a single dose of ondansetron $24 \mathrm{mg}$ p.o. with placebo and metoclopramide $10 \mathrm{mg}$ t.d.s. p.o. in the treatment of opioid-induced nausea and emesis in cancer patients. Support Care Cancer. 2002;10(3):231-236.

61. Corli O, Cozzolino A, Battaiotto L. Effectiveness of levosulpiride versus metoclopramide for nausea and vomiting in advanced cancer patients: a double-blind, randomized, crossover study. J Pain Symptom Manage. 1995;10(7):521-526.

62. Kim SW, Shin IS, Kim JM, et al. Mirtazapine for severe gastroparesis unresponsive to conventional prokinetic treatment. Psychosomatics. 2006;47(5):440-442. 
63. Koutsoumbi P, Epanomeritakis E, Tsiaoussis J, et al. The effect of erythromycin on human esophageal motility is mediated by serotonin receptors. Am J Gastroenterol. 2000;95(12):3388-3392.

64. Abrahamsson H. Treatment options for patients with severe gastroparesis. Gut. 2007;56(6):877-883.

65. Barone JA. Domperidone: a peripherally acting dopamine2-receptor antagonist. Ann Pharmacother. 1999;33(4):429-440.

66. Osborne RJ, Slevin ML, Hunter RW, Hamer J. Cardiotoxicity of intravenous domperidone. Lancet. 1985;2(8451):385.

67. Puisieux FL, Adamantidis MM, Dumotier BM, Dupuis BA. Cisaprideinduced prolongation of cardiac action potential and early after depolarizations in rabbit Purkinje fibres. Br J Pharmacol. 1996;117(7): 1377-1379.

68. Enger C, Cali C, Walker AM. Serious ventricular arrhythmias among users of cisapride and other QT-prolonging agents in the United States. Pharmacoepidemiol Drug Saf. 2002;11(6):477-486.

69. Stacher G, Gaupmann G, Steinringer H, et al. Effects of cisapride on postcibal jejunal motor activity. Dig Dis Sci. 1989;34(9):1405-1410.

70. Twycross R, Wilcock A, Charlesworth S, Dickman A. Palliative care formulary. 2nd ed. Oxford, UK: Radcliffe Medical Press; 2002.

71. McCallum RW, Prakash C, Campoli-Richards DM, Goa KL. Cisapride. A preliminary review of its pharmacodynamic and pharmacokinetic properties, and therapeutic use as a prokinetic agent in gastrointestinal motility disorders. Drugs. 1988;36(6):652-681.

72. Richelson E. Pharmacology of neuroleptics in use in the United States J Clin Psychiatry. 1985;46(8 Pt 2):8-14.

73. Kudo S, Ishizaki T. Pharmacokinetics of haloperidol: an update. Clin Pharmacokinet. 1999;37(6):435-436.

74. Skinner J, Skinner A. Levomepromazine for nausea and vomiting in advanced cancer. Hosp Med. 1999;60(8):568-570.

75. Patt RB, Proper G, Reddy S. The neuroleptics as adjuvant analgesics. J Pain Symptom Manage. 1994;9(7):446-453.

76. Dahl SG. Pharmacokinetics of methotrimeprazine after single and multiple doses. Clin Pharmacol Ther. 1976;19(4):435-442.

77. Bymaster FP, Calligaro DO, Falcone JF, et al. Radioreceptor binding profile of the atypical antipsychotic olanzapine. Neuropsychopharmacology. 1996;14(2):87-96.

78. Callaghan JT, Bergstrom RF, Ptak LR, Beasley CM. Olanzapine: pharmacokinetic and pharmacodynamic profile. Clin Pharmacokinet 1999;37(3):177-193.

79. Passik SD, Lundberg J, Kirsch KL, et al. A pilot exploration of the antiemetic activity of olanzapine for the relief of nausea in patients with advanced cancer and pain. J Pain Symp Manage. 2002;23(6): $526-532$.

80. Meltzer HY, Fibiger C. Olanzapine: a new atypical antipsychotic drug. Neuropsychopharmacology.1996;14(2):83-85.

81. Bhana N, Foster RH, Olney R, Plosker GL. Olanzapine: an updated review of its use in the management of schizophrenia. Drugs. 2001;61(1):111-161.

82. Gralla RJ, Itri LM, Pisko SE, et al. Antiemetic efficacy of high-dose metoclopramide: randomized trials with placebo and prochlorperazine in patients with chemotherapy-induced nausea and vomiting. $N$ Engl J Med. 1981;305(16):905-909.

83. Critchley P, Plach N, Grantham M, et al. Efficacy of haloperidol in the treatment of nausea and vomiting in the palliative patient: a systematic review. J Pain Symptom Manage. 2001;22(2):631-634.

84. Hardy JR, O'Shea A, White C, Gilshenan K, Welch L, Douglas C. The efficacy of haloperidol in the management of nausea and vomiting in patients with cancer. J Pain Symptom Manage. 2010;40(1): 111-116.

85. Buttner M, Walder B, von Elm E, Tramer MR. Is low-dose haloperidol a useful antiemetic?: a meta-analysis of published and unpublished randomized trials. Anesthesiology. 2004;101(6):1454-1463.

86. Passik SD, Lundberg J, Kirsh KL, et al. A pilot exploration of the antiemetic activity of olanzapine for the relief of nausea in patients with advanced cancer and pain. J Pain Symptom Manage. 2002;23(6): 526-532.
87. Twycross R, Bankby G, Hallowood J. The use of low-dose methotrimeprazine (levomepromazine) in the management of nausea and vomiting. Prog Palliat Care. 1997;5:49-53.

88. Mannix KA. Palliation of nausea and vomiting. In: Doyle D, Hanks G, Cherny NI, Calman K, editors. Oxford Textbook of Palliative Medicine. 3rd ed. Oxford, UK: Oxford University Press; 2004.

89. Wood CD, Cramer DB, Graybiel A. Antimotion sickness drug efficacy. Otolaryngol Head Neck Surg. 1981;89(6):1041-1044.

90. Twycross R, Wilcock A, Thorp S. PCF1. Palliative Care Formulary. London, UK: Radcliffe Medical Press; 1998.

91. Glare PA, Dunwoodie D, Clark K, et al. Treatment of nausea and vomiting in terminally ill cancer patients. Drugs. 2008;68(18):2575-2590.

92. Tan LB, Bryant S, Murray RG. Detrimental haemodynamic effects of cyclizine in heart failure. Lancet. 1988;1(8585):560-561.

93. Fick DM, Cooper JW, Wade WE, Waller JL, Maclean JR, Beers MH. Updating the Beers criteria for potentially inappropriate medication use in older adults: results of a US consensus panel of experts. Arch Intern Med. 2003;163(22):2716-2724.

94. Keeley PW. Nausea and vomiting in people with cancer and other chronic diseases. Clin Evid (Online). 2009;2009.

95. Gregory RE, Ettinger DS. 5-HT3 receptor antagonists for the prevention of chemotherapy-induced nausea and vomiting. A comparison of their pharmacology and clinical efficacy. Drugs. 1998;55(2): 173-189

96. Figg WD, Dukes GE, Pritchard JF, et al. Pharmacokinetics of ondansetron in patients with hepatic insufficiency. J Clin Pharmacol. 1996;36(3):206-215.

97. Gralla RJ, Osoba D, Kris MG, et al. Recommendations for the use of antiemetics: evidence-based, clinical practice guidelines. American Society of Clinical Oncology. J Clin Oncol. 1999;17(9): 2971-2994

98. Currow DC, Coughlan M, Fardell B, Cooney NJ. Use of ondansetron in palliative medicine. J Pain Symptom Manage. 1997;13(5):302-307.

99. Feuer DJ, Broadley KE. Corticosteroids for the resolution of malignant bowel obstruction in advanced gynaecological and gastrointestinal cancer. Cochrane Database Syst Rev. 2000;2:CD001219.

100. Czock D, Keller F, Rasche FM, Haussler U. Pharmacokinetics and pharmacodynamics of systemically administered glucocorticoids. Clin Pharmacokinet. 2005;44(1):61-98.

101. Ripamonti C, Twycross R, Baines M, et al. Clinical-practice recommendations for the management of bowel obstruction in patients with end-stage cancer. Support Care Cancer. 2001;9(4):223-233.

102. Maurer R, Gaehwiler BH, Buescher HH, Hill RC, Roemer D. Opiate antagonistic properties of an octapeptide somatostatin analog. Proc Natl Acad Sci U S A. 1982;79(15):4815-4817.

103. Martin BR, Wiley JL. Mechanism of action of cannabinoids: how it may lead to treatment of cachexia, emesis, and pain. J Supp Oncol. 2004;2(4):305-316.

104. Bagshaw SM, Hagen NA. Medical efficacy of cannabinoids and marijuana: a comprehensive review of the literature. J Palliat Care. 2002;18(2):111-122.

105. Walsh D, Nelson KA, Mahmoud FA. Established and potential therapeutic applications of cannabinoids in oncology. Support Care Cancer. 2003;11(3):137-143.

106. Beal JE, Olson R, Lefkowitz L, et al. Long-term efficacy and safety of dronabinol for acquired immunodeficiency syndrome-associated anorexia. J Pain Symptom Manage. 1997;14(1):7-14.

107. Rhodes VA, McDaniel RW. Nausea, vomiting, and retching: complex problems in palliative care. CA Cancer J Clin. 2001;51(4) 232-248.

108. Bruera E, Strasser F, Palmer JL, et al. Effect of fish oil on appetite and other symptoms in patients with advanced cancer and anorexia/ cachexia: a double-blind, placebo-controlled study. J Clin Oncol. 2003;21(1):129-134.

109. Van Fleet S. Relaxation and imagery for symptom management: improving patient assessment and individualizing treatment. Oncol Nurs Forum. 2000;27(3):501-510. 
110. Arakawa S. Relaxation to reduce nausea, vomiting, and anxiety induced by chemotherapy in Japanese patients. Cancer Nurs. 1997;20(5): 342-349.

111. Molassiotis A. A pilot study of the use of progressive muscle relaxation training in the management of post-chemotherapy nausea and vomiting. Eur J Cancer Care (Engl). 2000;9(4):230-234.

112. Mundy EA, DuHamel KN, Montgomery GH. The efficacy of behavioral interventions for cancer treatment-related side effects. Semin Clin Neuropsychiatry. 2003;8(4):253-275.

113. Ahles TA, Tope DM, Pinkson B, et al. Massage therapy for patients undergoing autologous bone marrow transplantation. J Pain Symptom Manage. 1999;18(3):157-163.

114. Grealish L, Lomasney A, Whiteman B. Foot massage. A nursing intervention to modify the distressing symptoms of pain and nausea in patients hospitalized with cancer. Cancer Nurs. 2000;23(3):237-243.

115. Pan CX, Morrison RS, Ness J, Fugh-Berman A, Leipzig RM. Complementary and alternative medicine in the management of pain, dyspnea, and nausea and vomiting near the end of life. A systematic review. J Pain Symptom Manage. 2000;20(5):374-387.

116. Hickok JT, Roscoe JA, Morrow GR, Ryan JL. A Phase II/III randomized, placebo-controlled, double-blind clinical trial of ginger (Zingiber officinale) for nausea caused by chemotherapy for cancer: a currently accruing URCC CCOP Cancer Control Study. Support Cancer Ther. 2007;4(4):247-250.

117. Storey PS. Obstruction of the GI tract. Am J Hosp Palliat Care. 1991;8(3):5.

118. Pothuri B, Meyer L, Gerardi M, Barakat RR, Chi DS. Reoperation for palliation of recurrent malignant bowel obstruction in ovarian carcinoma. Gynecol Oncol. 2004;95(1):193-195.

119. Pothuri B, Montemarano M, Gerardi M, et al. Percutaneous endoscopic gastrostomy tube placement in patients with malignant bowel obstruction due to ovarian carcinoma. Gynecol Oncol. 2005;96(2):330-334.

120. Cunningham MJ, Bromberg C, Kredentser DC, Collins MB, Malfetano JH. Percutaneous gastrostomy for decompression in patients with advanced gynecologic malignancies. Gynecol Oncol. 1995;59(2): 273-276.

121. Campagnutta E, Cannizzaro R, Gallo A, et al. Palliative treatment of upper intestinal obstruction by gynecological malignancy: the usefulness of percutaneous endoscopic gastrostomy. Gynecol Oncol. 1996;62(1):103-105.

122. Herman LL, Hoskins WJ, Shike M. Percutaneous endoscopic gastrostomy for decompression of the stomach and small bowel. Gastrointest Endosc. 1992;38(3):314-318.

123. Campagnutta E, Cannizzaro R. Percutaneous endoscopic gastrostomy (PEG) in palliative treatment of non-operable intestinal obstruction due to gynecologic cancer: a review. Eur J Gynaecol Oncol. 2000;21(4):397-402.

124. Guitron A, Adalid R, Huerta F, Macias M, Sanchez-Navarrete M. Palliative treatment of esophageal cancer with transendoscopic injection of alcohol. Rev Gastroenterol Mex. 1996;61(3):208-211. Spanish.

125. Nwokolo CU, Payne-James JJ, Silk DB, Misiewicz JJ, Loft DE. Palliation of malignant dysphagia by ethanol induced tumour necrosis. Gut. 1994;35(3):299-303.

126. Ahlquist DA, Gostout CJ, Viggiano TR, et al. Endoscopic laser palliation of malignant dysphagia: a prospective study. Mayo Clin Proc. 1987;62(10):867-874.

127. Brennan FN, McCarthy JH, Laurence BH. Endoscopic Nd-YAG laser therapy for palliation of upper gastrointestinal malignancy. Med J Aust. 1990;153(1):27-31.

128. Dallal HJ, Smith GD, Grieve DC, Ghosh S, Penman ID, Palmer KR. A randomized trial of thermal ablative therapy versus expandable metal stents in the palliative treatment of patients with esophageal carcinoma. Gastrointest Endosc. 2001;54(5):549-557.

129. Costamagna G, Shah SK, Tringali A, Mutignani M, Perri V, Riccioni ME. Prospective evaluation of a new self-expanding plastic stent for inoperable esophageal strictures. Surg Endosc. 2003;17(6):891-895.
130. Dormann AJ, Eisendrath P, Wigginghaus B, Huchzermeyer H, Deviere J. Palliation of esophageal carcinoma with a new selfexpanding plastic stent. Endoscopy. 2003;35(3):207-211.

131. Decker P, Lippler J, Decker D, Hirner A. Use of the Polyflex stent in the palliative therapy of esophageal carcinoma: results in 14 cases and review of the literature. Surg Endosc. 2001;15(12):144-147.

132. De Palma GD, di Matteo E, Romano G, Fimmano A, Rondinone G, Catanzano C. Plastic prosthesis versus expandable metal stents for palliation of inoperable esophageal thoracic carcinoma: a controlled prospective study. Gastrointest Endosc. 1996;43(5):478-482.

133. Mosca F, Consoli A, Stracqualursi A, Persi A, Lipari G, Portale TR. Our experience with the use of a plastic prosthesis and self-expanding stents in the palliative treatment of malignant neoplastic stenoses of the esophagus and cardia. Comparative analysis of results. Chir Ital. 2002;54(3):341-350. Italian.

134. Knyrim K, Wagner HJ, Bethge N, Keymling M, Vakil N. A controlled trial of an expansile metal stent for palliation of esophageal obstruction due to inoperable cancer. N Engl J Med. 1993;329(18):1302-1307.

135. Mosca F, Consoli A, Stracqualursi A, Persi A, Portale TR. Comparative retrospective study on the use of plastic prostheses and self-expanding metal stents in the palliative treatment of malignant strictures of the esophagus and cardia. Dis Esophagus. 2003;16(2):119-125.

136. Shimi SM. Self-expanding metallic stents in the management of advanced esophageal cancer: review. Semin Laparosc Surg. 2000;7(1):9-21.

137. Dormann A, Meisner S, Verin N, Wenk Lang A. Self-expanding metal stents for gastroduodenal malignancies: systematic review of their clinical effectiveness. Endoscopy. 2004;36(6):543-550.

138. Lelcuk S, Merhav A, Klausner JM, Gutman M, Greif F, Rozin R. Rectoscopic decompression of acute recto-sigmoid obstruction. Endoscopy. 1987;19(5):209-210.

139. Xinopoulos D, Dimitroulopoulos D, Theodosopoulos T, et al. Stenting or stoma creation for patients with inoperable malignant colonic obstructions? Results of a study and cost-effectiveness analysis. Surg Endosc. 2004;18(3):421-426.

140. Carne PW, Frye JN, Robertson GM, Frizelle FA. Stents or open operation for palliation of colorectal cancer: a retrospective, cohort study of perioperative outcome and long-term survival. Dis Colon Rectum. 2004;47(9):1455-1461.

141. Kimberly Moore Dalal, Marc J. Gollub, Thomas J. Miner, et al. Management of patients with malignant bowel obstruction and stage IV colorectal cancer. Journal of Palliative Medicine. 2011;14(7):822-828.

142. Woodruff R. Palliative medicine: evidence-based symptomatic and supportive care for patients with advanced cancer. 4th ed. Melbourne, Australia: Oxford University Press; 2004.

143. Dahl SG, Strandjord RE. Pharmacokinetics of chlorpromazine after single and chronic dosage. Clin Pharmacol Ther. 1977;21(4): 437-448.

144. Griffin DS, Baselt RC. Blood and urine concentrations of cyclizine by nitrogen-phosphorus gas-liquid chromatography. J Anal Toxicol. 1984;8(2):97-99.

145. Heykants J, Hendriks R, Meuldermans W, Michiels M, Scheygrond H, Reyntjens H. On the pharmacokinetics of domperidone in animals and man. IV. The pharmacokinetics of intravenous domperidone and its bioavailability in man following intramuscular, oral and rectal administration. Eur J Drug Metab Pharmacokinet. 1981;6(1): $61-70$.

146. Huang YC, Colaizzi JL, Bierman RH, Woestenborghs R, Heykants JJ. Pharmacokinetics and dose proportionality of domperidone in healthy volunteers. J Clin Pharmacol. 1986;26(8):628-632.

147. Ebert U, Siepmann M, Oertel R, Wesnes KA, Kirch W. Pharmacokinetics and pharmacodynamics of scopolamine after subcutaneous administration. J Clin Pharmacol. 1998;38(8):720-726.

148. Bateman DN. Clinical pharmacokinetics of metoclopramide. Clin Pharmacokinet. 1983;8(6):523-529.

149. Kutz K, Nuesch E, Rosenthaler J. Pharmacokinetics of SMS201-995 in healthy subjects. Scand J Gastroenterol Suppl. 1986;119:65-72. 
150. Chanson P, Timsit J, Harris AG. Clinical pharmacokinetics of octreotide. Therapeutic applications in patients with pituitary tumours. Clin Pharmacokinet. 1993;25(5):375-391.

151. Callaghan JT, Bergstrom RF, Ptak LR, Beasley CM. Olanzapine. Pharmacokinetic and pharmacodynamic profile. Clin Pharmacokinet. 1999;37(3):177-193.

152. Isah AO, Rawlins MD, Bateman DN. Clinical pharmacology of prochlorperazine in healthy young males. $\mathrm{Br} J$ Clin Pharmacol. 1991;32(6):677-684.

153. Taylor WB, Bateman DN. Preliminary studies of the pharmacokinetics and pharmacodynamics of prochlorperazine in healthy volunteers. Br J Clin Pharmacol. 1987;23(2):137-142.

154. Taylor G, Houston JB, Shaffer J, Mawer G. Pharmacokinetics of promethazine and its sulphoxide metabolite after intravenous and oral administration to man. Br J Clin Pharmacol. 1983;15(3):287-293.

155. Paton DM, Webster DR. Clinical pharmacokinetics of H1-receptor antagonists (the antihistamines). Clin Pharmacokinet. 1985;10(6): 477-497.

156. Dimmit DC, Choo YS, Martin LA, Arumugham T, Hahane WF, Weir SJ. Intravenous pharmacokinetics and absolute oral bioavailability of dolasetron in healthy volunteers: part 1. Biopharm Drug Dispos. 1999;20(1):29-39.

157. Lerman J, Sims C, Sikich N, et al. Pharmacokinetics of the active metabolite (MDL 74,156) of dolasetron mesylate after oral or intravenous administration to anesthetized children. Clin Pharmacol Ther. 1996;60(5):485-492.
158. Plosker GL, Goa KL. Granisetron. A review of its pharmacological properties and therapeutic use as an antiemetic. Drugs. 1991;42(5): $805-824$

159. Roila F, Del Favero A. Ondansetron clinical pharmacokinetics. Clin Pharmacokinet. 1995;29(2):95-109.

160. Simpson KH, Hicks FM. Clinical pharmacokinetics of ondansetron. A review. J Pharm Pharmacol. 1996;48(8):774-781.

161. Wilde MI, Markham A. Ondansetron. A review of its pharmacology and preliminary clinical findings in novel applications. Drugs. 1996;52(5):773-794.

162. Stoltz R, Cyong JC, Shah A, Parisi S. Pharmacokinetic and safety evaluation of palonosetron, a 5-hydroxytryptamine-3 receptor antagonist, in US and Japanese healthy subjects. J Clin Pharmacol. 2004;44(5):520-531.

163. Hunt TL, Gallagher SC, Cullen MT Jr, Shah AK. Evaluation of safety and pharmacokinetics of consecutive multiple-day dosing of palonosetron in healthy subjects. J Clin Pharmacol. 2005;45(5):589-596.

164. de Bruijn KM. Tropisetron. A review of the clinical experience. Drugs. 1992;43(Suppl 3):11-22.

165. Lee CR, Plosker GL, McTavish D. Tropisetron. A review of its pharmacodynamic and pharmacokinetic properties, and therapeutic potential as an antiemetic. Drugs. 1993;46(5):925-943.
Clinical Interventions in Aging

\section{Publish your work in this journal}

Clinical Interventions in Aging is an international, peer-reviewed journal focusing on evidence-based reports on the value or lack thereof of treatments intended to prevent or delay the onset of maladaptive correlates of aging in human beings. This journal is indexed on PubMed Central, MedLine, the American Chemical Society's 'Chemical

\section{Dovepress}

Abstracts Service' (CAS), Scopus and the Elsevier Bibliographic databases. The manuscript management system is completely online and includes a very quick and fair peer-review system, which is all easy to use. Visit http://www.dovepress.com/testimonials.php to read real quotes from published authors. 